\title{
Ownership and workforce composition: a counterfactual analysis of foreign multinationals and Italian uni-national firms
}

\author{
Mariachiara Barzotto $^{1} \mathbb{D} \cdot$ Giancarlo Corò $^{2} \cdot$ Ilaria Mariotti $^{3} \cdot$ Marco Mutinelli $^{4}$
}

Received: 27 January 2018 / Revised: 6 February 2019 / Accepted: 15 February 2019 /

Published online: 4 March 2019

(c) The Author(s) 2019

\begin{abstract}
This article investigates how the ownership of firms (affiliates of foreign multinational firms, or uni-national firms) affects their internal workforce composition. We consider this issue empirically by adopting a novel database on the workforce composition of companies operating in the manufacturing industry in north-east Italy. The workforce composition (in terms of skill level, gender and the less investigated characteristics of age and nationality) of affiliates of foreign multinational enterprises (FMNs) are compared with a counterfactual of uni-national firms, constructed using propensity score matching. Consistent with previous studies, the results report that FMNs recruit a larger number of highly-skilled workers. Our main findings show that FMNs employ a lower number of foreign and less experienced (young) workers. The employment of native and more experienced workers in FMNs seems to suggest that foreign companies use domestic 'inherited' stock of manufacturing knowledge and skills. By using this stock, they contribute to sustaining its development.
\end{abstract}

Keywords Foreign direct investments - Company workforce composition · Manufacturing · Veneto region

JEL Classification F23 $\cdot$ J24 $\cdot$ L6

\section{Introduction}

The characteristics of workers-i.e. employees' skill level, gender, age and nationality - matter for a broad variety of individual, firm, sector, and regional outcomes; such as knowledge transfer/sharing (e.g. Blomstrom and Kokko 2003), innovation (e.g. Fassio et al. 2018; Frosch 2011), and productivity (e.g. Hyun et al. 2015).

Mariachiara Barzotto

Mariachiara.Barzotto@newcastle.ac.uk

Extended author information available on the last page of the article 
Previous research in international business and international human resource management has focused primarily on these workers' characteristics as antecedents of innovation and productivity. The core argument is that workers' characteristics affect innovation and the productivity level of companies and sectors, as well as regions.

Less attention has been devoted to understanding if and how ownership-e.g. whether firms are affiliates of foreign multinational firms (FMNs), or uni-national firms/single domestic enterprises (NATs)_impacts on their internal workforce composition. Recent contributions have started to explore the relationship between offshoring and the composition of onshore workforce at the company level, comparing multinational enterprises with national ones (Becker et al. 2013). Yet, scant evidence is available on the effects of inward Foreign Direct Investments (FDIs) on the internal workforce composition, which is crucial for enhancing the competitiveness of companies (e.g. Frosch 2011) and, in turn, of regions and even countries (among others, Blomstrom and Kokko 2003). In particular, the relationship between ownership and the composition of a company's internal workforce (in terms of skills, gender, age, and nationality) is overlooked. The present article aims to explore the role of ownership in companies' employment behaviour, thus analysing if and how a company's internal workforce is affected by the firm's ownership status. The ownership status is qualified in terms of whether a firm under consideration is part of a foreign multinational group (FMN) or a single domestic enterprise/uni-national firm (NAT - a company that has neither been acquired in the period of analysis, nor invested abroad). More specifically, this article focuses on analysing whether internal workforce composition differs according to firm ownership, by comparing the employment choices made by FMNs with those of NATs. The article investigates how companies employ the local workforce, be they host-country nationals or foreigners, by looking at skill level, age, gender and nationality.

A deeper understanding of the employment behaviour adopted by FMNs and NATs, ultimately, aims to shed light on the extent to which the nature of employment changes according to the ownership. The aim of the approach is also to further our understanding of the use of native and experienced workers; in other words, workers with 'genomic, catalytic, organic and dynamic' (Kasabov and Sundaram 2016: 1529) competencies embedded in local industrial heritage. This is especially crucial, firstly, in countries for which the main source of competitiveness is manufacturing (such as Italy) and, secondly, in critical temporal windows, such as during the economic downturn originating with the global financial crisis, when the manufacturing sector was put under a strain worldwide.

The article contributes to the understanding of the relationship between firm ownership and the use of its workforce, in particular investigating employment choices, in terms of skill level, age, gender and nationality. It does so by exploring how firm ownership (FMN and NAT) affects a company's internal workforce composition during the economic crisis within the context of the Italian region of Veneto, a region renowned worldwide for its manufacturing heritage. In order to compare the employment choices made by FMNs with the ones undertaken by NATs and to test how firm ownership impact on a company's internal workforce composition, we adopt a novel database of manufacturing firms operating between 2007 and 2013 in the Italian region of Veneto. The dataset combines information on the internal 
workforce composition of companies along with data on their characteristics and economic performance. The region under investigation is located in north-east Italy and represents one of the leading manufacturing areas in the country and, more generally, in Europe. Descriptive statistics and counterfactual estimations have been developed to analyse the workforce composition of firms.

The remainder of the article is organised as follows. Section 2 presents a literature review on the effects of ownership on the internal workforce composition of host-country companies. Section 3 describes the presence of inward FDIs and the main characteristics of the local labour market composition in world-renowned manufacturing areas in advanced economies, such as Italy and, more specifically, the Veneto region. Section 4 is dedicated to the data and methodology of this study. Section 5 discusses the results of the analysis and, finally, Sect. 6 draws conclusions.

\section{Company workforce composition in relation to firm ownership}

FMNs and NATs are guided by different stakeholders (e.g. Bellak 2004; Douma et al. 2006) and, accordingly, driven by different goals. International business literature has highlighted how, on average, MNEs are larger, have higher capital intensity (Doms and Jensen 1998), and superior technology (Lipsey and Sjöholm 2005) than local firms (among others, Bandick 2008; Castellani and Zanfei 2006). These substantial differences between FMNs and NATs (Doms and Jensen 1998) affect company productivity and performance (Barbosa and Louri 2005); previous studies show that the first typology is more productive than the second (e.g. De Backer and Sleuwaegen 2003). FMNs have better access to foreign markets through their networks (Globerman et al. 1994), and this provides them with a wider range of information and, accordingly, a better capacity for evaluating situations (Caves and Caves 1996). The types of tools that FMNs can use in order to circumvent the requirements of national governments and regulations are more incisive than those used for the same purpose by NATs (e.g. transfer pricing) (Bellak 2004: 488). These forces impact on the human management strategies companies can undertake, as illustrated in the following sections.

\subsection{Skills and education}

Previous studies have mainly highlighted how the employment choices made by FMNs and NATs differ in terms of skills and educational level of their workforces. FMNs can draw on the managerial expertise of their parent company to manage complexity on a larger scale (Bellak 2004). Their organisational structure enables them to employ highly-skilled workers more easily (e.g. Bandick 2008) by using their economic power and/or by offering better career opportunities. This enables FMNs to overcome information asymmetry (Barba-Navaretti et al. 2006; Castellani and Zanfei 2006), as they have access to less information than local firms on the institutional and productive context, where they operate offshore. However, this strategy may weaken NATs by stealing the most skilled workers from the local 
labour market (Sylwester 2005). The high-quality jobs and higher labour productivity of FMNs compared to NATs is reflected in higher wages (Doms and Jensen 1998; Girma and Görg 2007). FMNs tend to hire highly-skilled employees in the host country and pay them more (Lipsey and Sjöholm 2005) than their national counterparts. As reported by Griffith and Simpson (2004), the proportion of skilled workers in the workplace, as well as wages for both skilled and operative workers, are higher in foreign-owned establishments than domestic-owned ones, in line with differences in labour productivity. Multinational enterprises (MNEs) rely more heavily on pay incentives to ensure quality and productivity, given the higher cost deriving from monitoring production activities from abroad (OECD 2008a). Moreover, labour productivity improves faster over time and with age in foreign-owned establishments (Griffith and Simpson 2004).

Empirical evidence shows that foreign subsidiaries are more involved in formal and informal training activities to improve the skill levels and professional profiles of their employees (Alfaro et al. 2004; De Mello 1999; Forte and Moura 2013; Loungani and Razin 2001; O’Donnell and Blumentritt 1999; Ozturk 2007). In particular, with regard to skilled labour-intensive industries in advanced countries, previous works (Driffield and Taylor 2000; OECD 2008b; UNCTAD 1994) report that training and development courses take place more frequently in the context of inward FDIs, in a variety of forms (on-the-job training, seminars, formal schooling, overseas education, see Blomstrom and Kokko 2003). Indeed, as Blomstrom and Kokko (2003: 11) report, the transfer of technology from multinational parent companies to their affiliates is "not only embodied in machinery, equipment, patent rights, and expatriate managers and technicians, but is also realised through the training of local employees [...] from simple manufacturing operatives through supervisors to technically advanced professionals and top-level managers".

Recent contributions have started exploring the composition of educational attainment (Becker and Muendler 2008; Jensen and Kletzer 2010), tasks (Lipsey and Sjöholm 2005), skills in offshoring (Blinder 2009) and onshore workforce at the company level, comparing MNEs with national ones (Becker et al. 2013). More specifically, this economic literature focuses on analysing the composition of offshoring and onshore workforce to discern tasks, occupations and workforce skills. Using propensity-score estimation, Becker and Muendler (2008) demonstrate that firms which expand abroad retain more domestic jobs than uni-national competitors. Thus, outward FDIs increase domestic-worker retention, especially that of highly educated workers. Worldwide offshoring affects the numbers of white-collar workers in a positive and statistically significant way (Becker et al. 2013). However, the positive effect of FDIs on domestic skill intensity decreases as investment shifts towards high-income countries (Head and Ries 2002). Offshoring is linked to a shift towards more non-routine (Gagliardi et al. 2015; Robert-Nicoud 2008) and more interactive tasks, as well as a shift towards highly educated workers, irrespective of whether MNEs expand or shrink their offshore employment (Becker et al. 2013). In particular, "the shift towards highly educated workers is in excess of what is implied by changes in either the task or the occupational composition" (Becker et al. 2013: 91). The authors highlight that offshoring towards low-income countries (Central and Eastern European countries excluded) leads to stronger onshore responses. Finally, 
they show that offshoring predicts between $10 \%$ and $15 \%$ of changes in the wage-bill shares of highly educated workers as well as measures of non-routine and interactive tasks. The opposite change in the task composition occurs at NATs; indeed, NATs reduce employment in non-routine and interactive tasks and raise employment in low-end tasks. However, they raise the employment of highly skilled workers, as do MNEs (Becker et al. 2013: 98).

We draw upon these recent contributions to further explore the inward component; in particular, we investigate the presence of any differences in terms of internal workforce composition between FMNs and NATs. Whilst the comparison in terms of presence of highly-skilled workers in FMNs and NATs is established in the literature (e.g. Bandick 2008; Lipsey and Sjöholm 2005), other characteristics, such as the age and nationality of employees, linked to their experience and local know-how heritage, have been less fully explored to date. In this study, we devote particular attention to these last two factors, which can be considered a proxy for idiosyncratic productive knowledge.

\subsection{Workers' age and nationality}

To the best of our knowledge, no evidence has been examined to date relating to the choices that FMNs make with regard to the nationality (national or foreign origin) of workers and, accordingly, to their experience. Indeed, Caprar (2011: 608) called for more research on local employees as FMNs rely heavily on local employees when conducting their international operations, yet the international business literature provides few instances of studies with a true focus on employees who are host-country nationals.

Previous studies on age (both on an individual level and a workforce age composition level) mainly focus on workers' capacity to innovate and how the age of individuals relates to their ability to produce economically relevant novelties. In particular, the great majority of previous studies on age and innovative performance at the individual level suggest that the capacity to produce economically relevant achievements follows a curvilinear, inversely u-shaped functional form with age, with most inventions being produced by individuals between the ages of 35 and 50, depending on the sector domain (Feyrer 2008; Frosch 2011: 415). Indeed, Giuri et al. (2007) and Mariani and Romanelli (2007) report how mean age of inventors varies across industries, in knowledge-intensive sectors (such as information technology, optics or biotechnology) and how inventors in such sectors tend to be younger (early 40s) than in more experience-based fields (such as agriculture or metallurgy) and most engineering disciplines. In these last two categories, mean ages for inventors range from the mid-40s to the late 40s (Frosch 2011; Henseke and Tivig 2009; Jones 2005; Simonton 1988, 2007). In her critical discussion of existing studies exploring the effects of age on innovative performance, Frosch (2011) reports that productivity is found to be lower for less experienced workers with shorter tenures in their current plant (Ilmakunnas et al. 2004: 271), highlighting the relevance of productivity enhancements through learning-by-doing (Malmberg et al. 2008). 
With regard to the nationality dimension, research on migrant workers predominately focuses on the effects of immigration on total output and innovation. This stream of research (e.g. Huber and Tondl 2012; Paserman 2013) seems to indicate that migrants per se are neither beneficial nor detrimental for innovation and/or productivity. ${ }^{1}$ This result is transversal at all levels (plant, regional or country level). Evidence on the impact of migration on innovation largely concerns the skills of migrant workers and adopts geographical level data (Hunt and Gauthier-Loiselle 2010 and Kerr and Lincoln 2010 for the USA; Niebuhr 2010 for Germany; Gagliardi 2015 for the UK; Bratti and Conti 2018 for Italy; and Bosetti et al. 2015 for a crosscountry study). Positive impacts on innovation and/or productivity mainly depend on the specific skills and attributes of migrant workers and the sectors in which they operate. In sectors with a predominance of manual tasks, immigrant workers exert a positive impact on output, which is mainly driven by an increase in total factor productivity (Aleksynska and Tritah 2015; Etzo et al. 2017; Peri 2012), as well as on innovation (for a review see Jensen 2014). Looking at innovation in manufacturing sectors, Fassio et al. (2018: 1) show that highly-educated migrants have a positive effect on innovation, but the effect differs across industries. This effect is stronger in industries with low levels of over-education (that is, when workers are employed in occupations requiring a lower level of education than the one that they have attained). ${ }^{2}$ Evidence from the United States seems to largely point to a direct positive effect of skilled immigration on innovation activities, while, in Europe, the evidence is more mixed. Some studies report that migrants contribute positively to the number of patents and citations in scientific publications in European countries (Bosetti et al. 2015; Gagliardi 2015), whilst other research suggests that this might not always be the case (e.g. Ozgen et al. 2017; Zheng and Ejermo 2015). This mixed result could be due to the different nature of skilled immigration in different locations around Europe (Fassio et al. 2018: 2). For instance, southern European countries, such as Spain (Kangasniemi et al. 2012) or Italy (Bratti and Conti 2018), tend to be destinations for unskilled migrants. In particular, Italy is a country which is exposed to a very rapidly increasing and large wave of immigrants who are mostly poorly educated and come from developing countries (Bratti and Conti 2018). Looking at the effects of immigration in Italy, in their study, Bratti and Conti (2018) find no evidence of either positive or negative effects of migrants on innovation. In their analysis of the fashion sector in the Veneto Region, ${ }^{3}$ Morrison and Sacchetto (2016) highlighted how immigrants tend to perform low-skilled tasks (Perrotta and

\footnotetext{
1 Other studies explore ethnic diversity and nationality compositions on outcome (such as innovation or performance) at the company level, sector level and country level (e.g. Østergaard et al. 2011). For instance, the study by Hyun et al. (2015) explores how the composition of management teams and employee groups, according to nationality, in foreign subsidiaries can affect subsidiary performance. They found that balanced compositions in both subsidiary management teams and subsidiary employee groups were positively associated with subsidiary performance.

${ }^{2}$ Fassio et al. (2018: 1) show that highly-educated migrants have a positive effect on innovation and the effect is stronger in case of high levels of FDIs and openness to trade and, finally, in industries with higher ethnic diversity (Breschi et al. 2017; Saxenian 2006).

3 For more information on hirings, please refer to the "Veneto Lavoro" website: http://www.venetolavo ro.it.
} 
Sacchetto 2009). Lovison (2005-2006) reported the presence of segmentation phenomena within the pool of low-skill jobs among foreign workers. More specifically, in the textile and apparel sector, foreign workers coming from Africa mainly undertake employment linked to ironing jobs, whilst workers of Asian origin are more likely to carry out simple sewing activities.

In contexts like Italy, in which manufacturing plays an important role, ${ }^{4}$ the inherited 'genomic, catalytic, organic and dynamic' (Kasabov and Sundaram 2016: 1529) knowledge embedded in local industrial heritage is crucial for the sustainability of this sector. The stickiness of knowledge to a specific geographical context depends on native workers; indeed, local knowledge sticks to a particular place only to the extent to which workers mastering this know-how continue to work in the territory and do not migrate. From the perspective of an FMN, the age and nationality of employees might play an important role in reducing the burden of information asymmetries. Since age and nationality are often linked with expertise, FMNs might decide to employ more experienced (instead of younger) and national (instead of immigrant) workers than NATs. This would allow companies to cope with the liability of foreignness (Zaheer 1995). It would also enable them to tap into locally embedded stocks of knowledge, skills and technology present in the region and developed due to previous efforts undertaken by governments and local firms. This is juxtaposed with the fact that migrants are likely to be subject to the vertical overeducation (Nieto et al. 2015) phenomenon. Fassio et al. (2018: 3) have suggested that "over-education might differ quite a lot between different industries: in industries in which national standards and country-specific tacit knowledge play a large role, skilled migrant workers might find it harder to work in the occupations that are related to their education attainments. On the contrary in industries that rely more on codified knowledge, the opposite might occur". More specifically, their study shows that the contribution of skilled immigrants on innovation is only positive and significantly different from zero in sectors with low levels of over-education.

Thus, we expect a higher presence of national (instead of immigrants) and mature (instead of young) workers in FMNs than NATs.

\section{Overview of foreign multinational firms and the workforce in Italy and Veneto}

At the end of 2014, there were 13,569 firms under foreign control in Italy (ISTAT 2016); these were companies that employed about 1,227,000 workers, equal to $7.6 \%$ of the national total. FMNs contributed to $17.8 \%$ of the total manufacturing industry and services turnover, $14.1 \%$ of value added and $14.6 \%$ of investments.

\footnotetext{
${ }^{4}$ Manufacturing still plays an important role in European economies: each additional manufacturing job is found to be able to create 0.5-2 jobs in other sectors in Europe (Rueda-Cantuche et al. 2012). In 2012, manufacturing represented the second largest sector within the EU-28's non-financial economy in terms of its contribution to employment $(22.4 \%)$ and value added (26.2\%) (EUROSTAT 2015). For further information on the Italian case, see ISTAT (2017).
} 
The contribution of FMNs to national research and development (R\&D) expenditure $(23.9 \%)$ and to trade exchange is of particular importance since they generated more than a quarter of the national goods exports $(27.4 \%)$ and almost half of imports (46.5\%). According to Prometeia (2014), the Italian companies that became part of foreign multinational groups grew in terms of sales thanks to the opportunity to serve new markets through the buyer's sales channels. Productivity growth also occurred as a result of the adoption of more efficient work organisation systems, without, however, leading to job losses. In contrast, increases in market shares generated employment growth, improving the company's relationship with the territory.

Foreign investments in the Italian manufacturing sector mainly relate to high scale economies (40.9\% of the inward FDIs), specialised suppliers (i.e. mechanics and electro mechanics $26.6 \%$ ), high-tech sectors (18.6\%), and traditional industries (especially fashion, furniture, and food-14.3\%) (Mariotti et al. 2014). The concentration of investments in the medium-high and high-tech sectors is linked to market demand and the market potential of these sectors, whilst investments in traditional low-tech sectors are linked to products 'Made in Italy', which are usually produced in industrial districts. In particular, the Italian industrial system is distinctive in nature; competitiveness is grounded in a specific structure based on several clusters. Such a structure allows the use of agglomerative advantages, also boosted by the proximity between suppliers and users (Mariotti et al. 2008; Porter 1985).

The comparison between NATs and FMNs in Italy reveals substantial differences in economic performance, specifically in relation to labour productivity and profitability. Added value per employee, investments per employee and incidence of gross operating margin on added value are substantially doubled in companies with foreign control compared to those with national control, and R\&D expenses are almost four times higher (Mariotti et al. 2008).

The cost of labour is also significantly higher in manufacturing industry (over 57,000 euro against 39,000) and in services $(45,000$ against 28,000$)$. This heterogeneity can be explained by differences primarily in size (an average of 113.5 employees in companies with foreign control compared to 5.2 in national firms, in the manufacturing industry, and 80.9 vs. 3.0 employees in services) but also in structure. However, when restricting the analysis to companies with more than 250 employees, the performance differential decreases but it is still positive. The added value per employee of FMNs equals 69,300 euros, compared to 57,900 euros for national companies; the impact of the net operating margin on value added equals $34.2 \%$ for foreign-controlled companies, while that on national firms is $30.6 \%$. Moreover, the levels of labour productivity and profitability are, on average, higher for companies under foreign control, with more pronounced differences in the sectors with higher technological content, such as chemistry, electronics and instrumental mechanics. The main reason explaining the differences between foreign-owned and national firms is the sector of specialisation: inward FDIs concentrate on more advanced technological areas compared to Italian firms (Mariotti et al. 2008). 
Table 1 Workforce composition in Italy in 2011-2013 (Source: Authors' elaboration on ISTAT data)

\begin{tabular}{|c|c|c|c|c|c|c|}
\hline \multirow[t]{2}{*}{ Job } & \multicolumn{2}{|l|}{2011} & \multicolumn{2}{|l|}{2012} & \multicolumn{2}{|l|}{2013} \\
\hline & Absolute value & $\%$ & Absolute value & $\%$ & Absolute value & $\%$ \\
\hline Director & 115,732 & 1 & 110,685 & 1 & 108,113 & 1 \\
\hline Manager & 442,229 & 4 & 420,178 & 4 & 420,013 & 4 \\
\hline Clerical & $4,442,636$ & 37 & $4,277,729$ & 37 & $4,235,758$ & 37 \\
\hline Worker & $6,460,890$ & 54 & $6,320,920$ & 54 & $6,128,998$ & 54 \\
\hline Apprentice & 489,391 & 4 & 454,766 & 4 & 437,583 & 4 \\
\hline Other & 96,845 & 1 & 64,125 & 1 & 61,657 & 1 \\
\hline Total & $12,047,723$ & 100 & $11,648,406$ & 100 & $11,392,124$ & 100 \\
\hline
\end{tabular}

Inward FDIs are unevenly distributed in Italy. Northern regions account for almost $80 \%$ of the grand total. The Veneto region, which represents the focus of the present study, attracted about $12 \%$ of inward FDIs and registered the highest inward FDI growth $(+42 \%)$ between 2000 and 2013..$^{5}$

As far as the employment structure of the operating firms in Italy is concerned, in the period between 2011 and 2013, 5\% of all employees were highly skilled (directors and managers), the rest were low skilled (37\% clericals and 54\% workers, respectively) (see Table 1). The employment composition of firms in Italy is linked to the country's industrial specialisation based on mature and low value-added industries (De Benedictis 2005), in which low-skilled workers are more likely to be employed.

When analysing the employment composition of firms in Italy, it is worth considering immigrant workers. In the last two decades, immigration has become a relevant phenomenon in Italy. The share of foreigners in the population has more than tripled, passing from 1.3 million in the 2001 census to 4 million in 2011 (ISTAT 2015). During the same period, the relative size of the immigrant population rose from $2.3 \%$ in 2001 to $6.8 \%$ in 2011 (Etzo et al. 2017). The great majority of foreigners come from less developed or emerging economies. ${ }^{6}$ Foreigners tend to settle in the richest regions and in big cities: in 2010, the provinces of Milan (north-west) and Rome (central) alone accounted for $18 \%$ of all Italian immigrants (Bratti and Conti 2018). Immigrants in Italy are overwhelmingly poorly educated: $10.89 \%$ have only primary education, $33.72 \%$ lower secondary education, $44.86 \%$ upper-secondary education and $10.52 \%$ a university degree or higher (Table 2 ). The ratio between natives and foreign workers shows that the latter are relatively less educated. Italy, compared with other countries, is mostly characterised by young and low-skilled

\footnotetext{
5 The choice to investigate the direct effects of inward FDIs in the Veneto region is due to the pivotal role of the manufacturing sector in the economy of the region and its high export propensity $(40 \%$ of GDP). Veneto has traditionally been considered a world-renowned economic area for manufacturing production, due to the industrial districts in the 'Made in Italy' sectors.

6 The top five countries by number of immigrants in 2010 were Romania, Albania, Morocco, China and Ukraine, accounting for about 50\% of the total foreign-born population (Bratti and Conti 2018 on ISTAT, Demographic Portal).
} 
Table 2 Native and immigrant workers: education attainment (2011) (Source: Etzo et al. (2017: 8) and Istat data)

\begin{tabular}{lcll}
\hline Educational attainment & Natives (\%) & Immigrants (\%) & $\begin{array}{l}\text { Natives/ } \\
\text { immi- } \\
\text { grants }\end{array}$ \\
\hline Primary education & 4.65 & 10.89 & 0.43 \\
Lower-secondary & 29.86 & 33.72 & 0.88 \\
Upper secondary & 46.83 & 44.86 & 1.04 \\
University degree and more & 18.66 & 10.52 & 1.77 \\
\hline
\end{tabular}

immigrants (Del Boca and Venturini 2005). Foreign workers are disproportionately employed in low-skill intensity sectors, and they account for at least $10 \%$ of all value added, and their role is crucial in the construction sector (Etzo et al. 2017). The scant attractiveness to highly-skilled foreign workers is also due to the lower returns on human capital for immigrants than for natives (Bratti and Conti 2018). Indeed, human capital acquired in foreign (especially developing) countries is poorly transferable and usually does not enable migrants to gain access to high-paying occupations (Dell'Aringa et al. 2015). Foreign workers undertake jobs which tend to be less qualified compared to the worker's educational attainment and skills (overeducation phenomenon). This is mainly due to: (1) poor knowledge of the Italian language; (2) lack of recognition of the education title achieved abroad; (3) socio-cultural motivations (ISTAT 2015); (4) discrimination in the labour markets of the host country (Fassio et al. 2018). As recently highlighted by Fassio et al. (2018: 3), trade unions or the corporatism of specific manufacturing sectors might affect the way in which foreign competencies are integrated into the workplace.

\section{Data and methodology}

This analysis focuses on how firm ownership (FMNs or NATs) affects the internal workforce composition of companies, with a specific focus on companies located in an area where the manufacturing sector represents an important source of competitiveness. We tackle this issue by investigating the role of ownership in a specific temporal window, the economic downturn, during which this crucial sector has been put under strain. The study considers manufacturing companies, both foreign-owned and domestic-owned, that have more than ten employees and are located in the Italian region of Veneto. Whilst foreign-owned companies are affiliates of foreign multinational enterprises, uni-national firms are Italian firms that have neither been acquired by nor merged with foreign companies, nor have they invested abroad. For these reasons, the analysis of firms located in the same region allows us to monitor the legal, cultural and economic framework of the case analysed.

The study adopts a uniquely rich dataset which combines the following three sources of data (Table 3): 
Table 3 Variables and data source

\begin{tabular}{|c|c|c|c|c|}
\hline Label & Variable & Unit & Year & Source \\
\hline \multirow[t]{3}{*}{ Firm characteristics } & Ownership & Dummy variable & 2007-2013 & Reprint \\
\hline & Sector & Dummy variable & 2007-2013 & AIDA \\
\hline & Firm size (Turnover) & Thousands of Euros & 2007-2013 & AIDA \\
\hline \multirow[t]{4}{*}{ Performance } & Labour cost per employee & Thousands of Euros & $2007-2013$ & AIDA \\
\hline & Value added per employee & Thousands of Euros & 2007-2013 & AIDA \\
\hline & ROE & Percentage & 2007-2013 & AIDA \\
\hline & $\begin{array}{l}\text { Operating profit per } \\
\text { employee }\end{array}$ & Thousands of Euros & 2007-2013 & AIDA \\
\hline \multirow[t]{4}{*}{ Workforce composition } & $\begin{array}{l}\text { Share of high skilled } \\
\text { workers }\end{array}$ & $\begin{array}{l}\text { Share based on number of } \\
\text { workers }\end{array}$ & $2008 ; 2014$ & SILV \\
\hline & Share of under 30 workers & $\begin{array}{l}\text { Share based on number of } \\
\text { workers }\end{array}$ & $2008 ; 2014$ & SILV \\
\hline & Share of women workers & $\begin{array}{l}\text { Share based on number of } \\
\text { workers }\end{array}$ & $2008 ; 2014$ & SILV \\
\hline & Share of foreign workers & $\begin{array}{l}\text { Share based on number of } \\
\text { workers }\end{array}$ & $2008 ; 2014$ & SILV \\
\hline
\end{tabular}

1. The Reprint Database was developed by Ricerche and Progetti and the Polytechnic of Milan, and sponsored by the Italian Institute for External Trade (ITA-ICE). Since 1986, the Reprint has recorded the flows of inward and outward manufacturing FDIs which have occurred in Italy (for details see Mariotti et al. 2014). This dataset was updated in 2014 and comprises detailed information which also includes the investment year, sector, FDI typology and country of origin of the inward FDIs in the Veneto region.

2. The AIDA Database, by the Bureau van Dijk, provides the balance sheet data of active Italian firms. This dataset allows us to retrieve data on the balance sheets of manufacturing firms located in Veneto from 2007 to 2013.

3. The SILV (Informative System Veneto Labour) Dataset was developed by Veneto Lavoro, and it includes information about the employment composition (age, gender, citizenship, professional activity, educational qualification, type of contract, new hirings/dismissals) of every single firm active in Veneto between 2008 and 2014. By matching the three datasets, it is possible to compare the economic and employment structure of FMNs and NATs.

Data on the characteristics and performance of firms refer to the period between 2007 and 2013. Meanwhile, data on the labour composition have a 1-year lag (2008 and 2014), in order to determine the effects of the characteristics and performance of the companies on their labour composition.

Firstly, we carry out descriptive statistics to analyse inward FDIs in Veneto, in terms of both the sector and country of origin. We examine the dynamics of the NATs and FMNs according to their size, workers' qualifications, productivity, profitability and the characteristics of the production process. 
Secondly, we perform a counterfactual analysis, with a control group of NATs selected based on similarity to sector and the economic profile of the FMNs (in particular, size and return of equity-ROE). In order to isolate the effect of foreign ownership, we build an appropriate counterfactual of national firms which are as similar as possible to foreign-owned companies' affiliates of multinational enterprises (Barba-Navaretti et al. 2009: 241). We apply the method of propensity score matching (Rubin 1974) to overcome the self-selection problem, allowing the condition of a natural experiment with non-experimental data to be established (Heckman et al. 1997; see Barba-Navaretti et al. 2009 for a literature review of contributions in international economics using propensity score matching and see Becker and Muendler 2008 on the effect of FDIs on job security). The propensity score estimates the probability of being an FMN as conditional on a number of observables (Becker and Ichino 2002; Brouwer and Mariotti 2014; Caliendo 2008). Specifically, such a counterfactual dataset has been defined by matching the FMNs with firms from the NAT sample which have been selected based on the following three characteristics: sector (OECD classification of manufacturing industries, which refers to their global technological intensity); return of equity (ROE); and size (expressed in terms of natural logarithm of the turnover in 2010). The turnover referred to the data in 2010 in order to control for the argument of cherry-picking FMNs. In fact, it could be argued that the best performing local firms were taken over by foreign investors (see, among others, Crinò 2010; Crinò and Onida 2007). Subsequently, for each FMN, one or more cases of companies with a sufficiently close propensity score are identified (Barba-Navaretti et al. 2009: 242).

We run a logit regression of the probability of being FMNs (which corresponds to 1 if the company has foreign participation) as a function of company attributes, such as size, ROE and sector dummy variables. The multinomial logit estimation allowed us to compute, for each single company, the probability of being an FMN. With these propensity scores, we run the matching algorithm (Barba-Navaretti et al. 2009: 250).

Once coherent control group for FMNs was found, and we compare different outcome variables with the NATs: internal workforce composition (share of highlyskilled workers, ${ }^{7}$ share of under-30 workers, share of women and share of foreign workers), labour cost per employee, value-added per employee and operating profit per employee. This allows us to estimate the effect of being an affiliate of a foreignowned multinational enterprise. Such an effect is obtained by computing the difference between the FMNs and the NATs in terms of the average mean of the outcome variables. This is called the Average Treatment Effect on the Treated (ATT) and is computed as follows:

$$
\alpha_{A T T}=\gamma^{1}-\gamma^{0}
$$

\footnotetext{
${ }^{7}$ We defined highly-skilled workers as managers, professionals and technicians and associate professionals. Further detail on the complete list of the classification of the occupations used can be found in Appendix 1.
} 
Table 4 Inward FDI in Veneto and NATs in 2013 by OECD classification (NACE Rev. 1.1)

\begin{tabular}{lrrrrr}
\hline OECD classification & \multicolumn{2}{l}{ NATs } & & \multicolumn{2}{l}{ FMNs } \\
\cline { 2 - 3 } \cline { 5 - 6 } & N & $\%$ & & $\mathrm{~N}$ & $\%$ \\
\hline High-tech & 357 & 4.00 & & 23 & 10.50 \\
Medium-high tech & 2054 & 23.03 & & 101 & 46.12 \\
Medium-low tech & 3517 & 39.43 & 55 & 25.11 \\
Low tech & 2992 & 33.54 & & 40 & 18.26 \\
Total & 8920 & 100 & & 219 & 100 \\
\hline
\end{tabular}

where $\gamma^{1}$ is the value of an outcome variable of the FMNEs, and $\gamma^{0}$ is the value of an outcome variable of the control group (NATs) (Barba-Navaretti et al. 2009: 242).

We run a 5-nearest neighbour matching method (following a random draw) with replacement and caliper $(=0.01)$, ultimately conditioning on the common support.

This method identifies the control company with the close propensity score for each FMN. As previously mentioned, we run our matching according to size, ROE and sector. This ensures that each firm size (expressed in terms of turnover) $x$, ROE $z$ and sector $j$ is matched with a control firm of the same size, ROE and sector. Building on Barba-Navaretti et al. (2009: 251) work, a good match should also result in characteristics of the counterfactual of national firms being as close as possible to FMNs. In formal terms, the matched sample should satisfy the balancing property, that is, the distribution of the vector of observables should be balanced across FMNs and control firms. This specific matching method has been applied in response to the goodness of fit of the statistical model. The sample validity has been checked through an econometric test that the balancing property holds. ${ }^{8}$

The new sample resulting from the p-score matching (counterfactual analysis) was composed of 193 FMNs and 671 NATs.

\section{FMNs vs. uni-national firms: comparison and counterfactual analysis}

The analysis of the dataset of NATs and FMNs points out that about $57 \%$ of FMNs operate in the high- and medium-tech sectors, while about $73 \%$ of the NATs are in the low-high and low-technology sectors (see Table 4).

This conclusion is consistent with the evidence that foreign investors tend to acquire market shares in technologically advanced sectors. Simultaneously, they also invest in Italian firms that specialise in the sectors that most often characterise 'Made in Italy', which are traditionally low-tech. This complementarity in the

\footnotetext{
${ }^{8}$ Using STATA15, we use "pstest" to calculate the extent of balancing of the set of confounders we used to define the appropriate control group. We use the command "pstest" after we run "psmatch2" (Leuven and Sianesi 2003). We apply the option "both", which considers bias before and after matching. This command offers several measures of balancing. In balancing property holds, "Bias" should be $<5 \%$. Further details can be found in Appendix 2.
} 


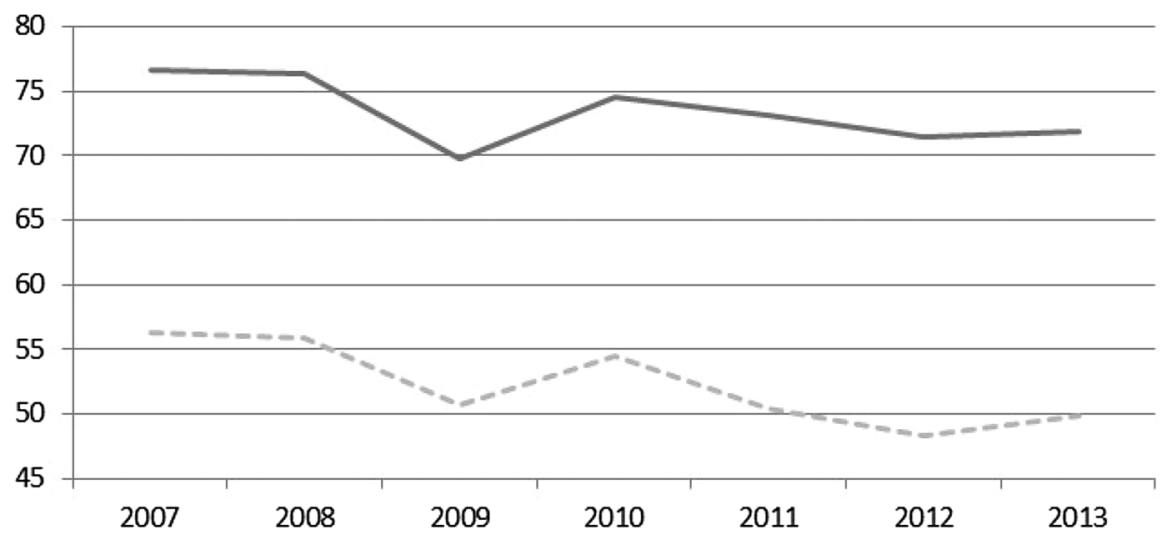

Note: NATs dotted line, FMNs solid line.

Fig. 1 NATs' and FMNs' value added per employee (2007-2013), pre-counterfactual. Note: NATs dotted line, FMNs solid line

industrial structure could represent a first interesting result that explains why FMNs follow a specific location strategy. FMNs locate themselves in those economic spaces (in technologically advanced sectors) that are less covered by local business. The presence of FMNs in these sectors may lead to an efficient economic allocation, which supplies national industries (operating mainly in low-tech industry) with the technologies they lack locally.

The origin of investments in the Veneto region is similar to that within the whole of Italy. Indeed, the strong presence of neighbouring advanced countries (Germany, France and UK) and emerging ones (such as China, India and the Russian Federation) can be observed.

NATs and FMNs show different characteristics. First of all, the two groups of firms are heterogeneous with regard to their size (turnover). In fact, FMNs are seven times larger than NATs on average. Also, the qualification of their workers usually differs. In this respect, the affiliates of FMNs show almost double the percentage of highly-skilled employees compared to the NATs (30\% vs. 16\%). Nevertheless, the number of highly-skilled employees has been increasing, both in FMNs and NATs, over time.

The low level of willingness to hire foreign workers might be related to three main motivations: (1) the low share of foreign population aged 15 or above in Italy, which is about $8 \%$, and $10 \%$ in the north-east, where Veneto is located (ISTAT $2017)$; (2) that fact that foreign workers in Italy are mainly an unskilled and on temporary contracts; and (3) the fact that foreign workers' occupations tend to require fewer qualifications than their actual education attainment and competencies due to poor knowledge of the Italian language, lack of recognition of the education title achieved abroad and socio-cultural motivations (ISTAT 2015).

Moreover, the productivity (value added per employee) and labour cost per employee over the period 2007-2013 (Figs. 1, 2) distinguish NATs from FMNs as 


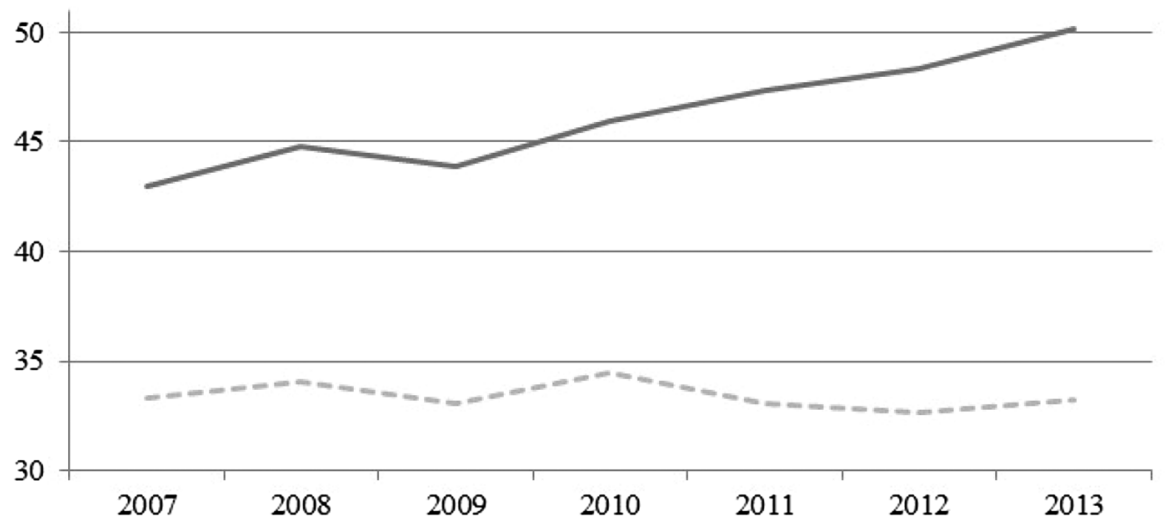

Note: NATs dotted line, FMNs solid line.

Fig. 2 NATs' and FMNs' cost of labour per employee (2007-2013), pre-counterfactual. Note: NATs dotted line, FMNs solid line

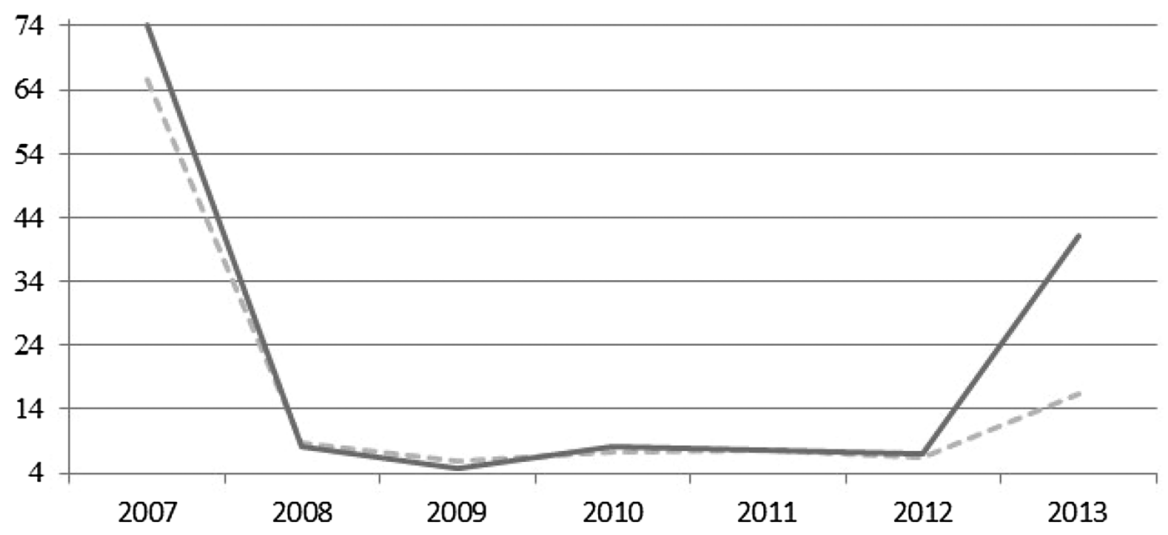

Note: NATs dotted line, FMNs solid line.

Fig. 3 NATs' and FMNs' ROI (2007-2013), pre-counterfactual. Note: NATs dotted line, FMNs solid line

well. Specifically, FMNs exhibit higher values in both dimensions. The result is in line with previous evidence (e.g. Griffith and Simpson 2004). Such ranges widened during the period considered. FMNs exhibit higher values, both in terms of ROI and operating profit per employee, almost constantly (Figs. 3, 4).

The logit model allows us to develop an appropriate counterfactual of the NATs, which takes into consideration the size, ROE and sector of the firms. Such an analysis shows that the FMNs tend to be larger in terms of turnover than the NATs. Additionally, they are more open to the high-tech sector than to other sectors (Table 5), as previously shown in the descriptive analysis. This finding is consistent with the 


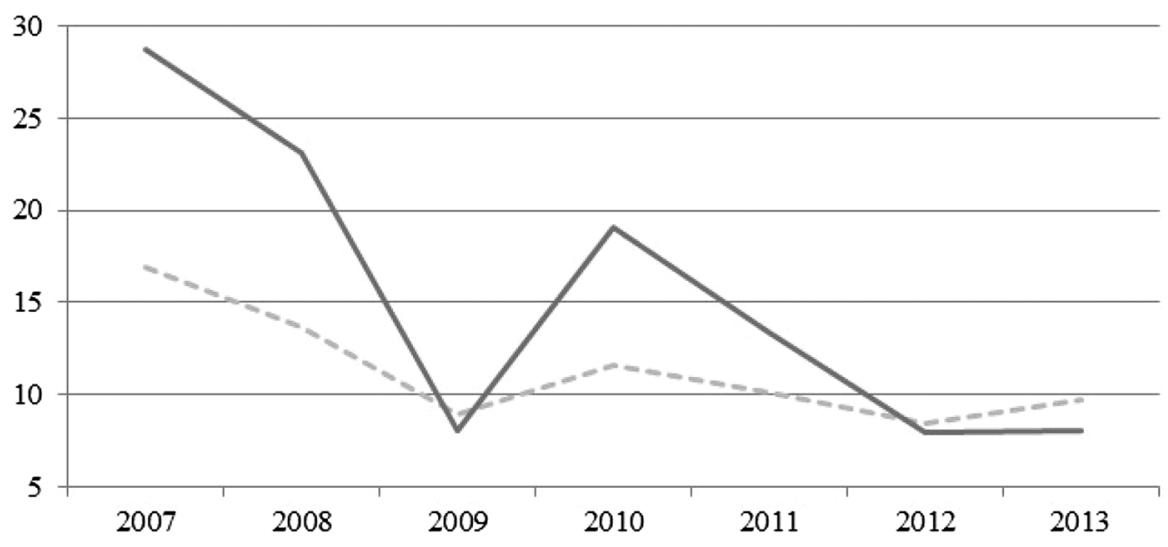

Note: NATs dotted line, FMNs solid line.

Fig. 4 NATs' and FMNs' operating profit per employee (2007-2013), pre-counterfactual. Note: NATs dotted line, FMNs solid line

Table 5 Logistic regression

\begin{tabular}{ll}
\hline Variable & Coefficient \\
\hline Turnover 2010 (logarithm) & $1.04 * * *$ \\
ROE 2010 & -0.01 \\
Medium/high-tech sector & $-0.64 * * *$ \\
Medium/low-tech sector & $-1.58 * * *$ \\
Low-tech sector & $-2.03 * * *$ \\
Constant & $-11.36^{* * *}$ \\
Number of observations & 8369 \\
Prob $>$ chi ${ }^{2}$ & 0.00 \\
Pseudo ${ }^{2}$ & 0.25 \\
Log likelihood & -724.08 \\
\hline
\end{tabular}

$*, * *, * * *$ are significant at $10 \%, 5 \%$ and $1 \%$, respectively

evidence that the R\&D investment per employee in Italian manufacturing firms is, on average, four times higher in the affiliates of foreign MNEs. This figure is five times higher in the services (Mariotti et al. 2008).

With regard to the counterfactual analysis, it takes into consideration a control group that selects from among all NATs, those that are structurally similar to FMNs in terms of size, ROE and sectors. The 'dynamics' characterising the two groups of firms do not significantly differ from the previous analysis on the total sample in terms of value-added per employee, labour cost and profitability (Figs. 5, 6, 7, 8). Nonetheless, the differences become less significant, but present with the same trend. However, profitability constitutes an exception as the NATs seem to perform better in terms of operating profit per employee. In other words, the NATs show a lower value added per employee, but appear more profitable in line with the evidence 


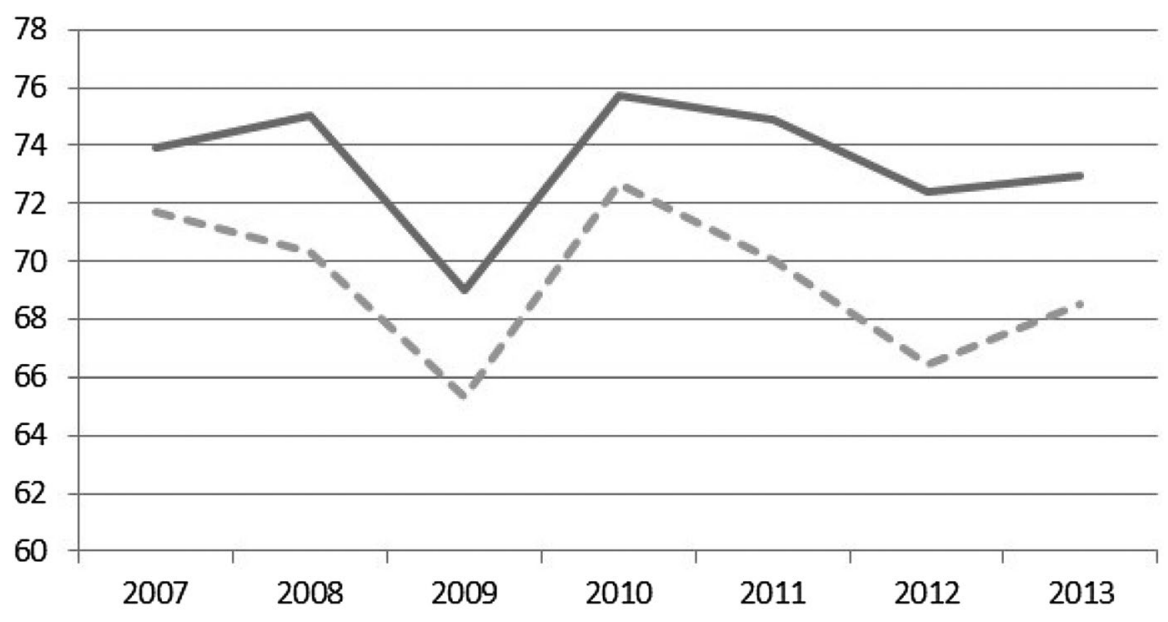

Note: NATs dotted line, FMNs solid line.

Fig. 5 NATs' and FMNs' value added per employee (2007-2013), post-counterfactual. Note: NATs dotted line, FMNs solid line

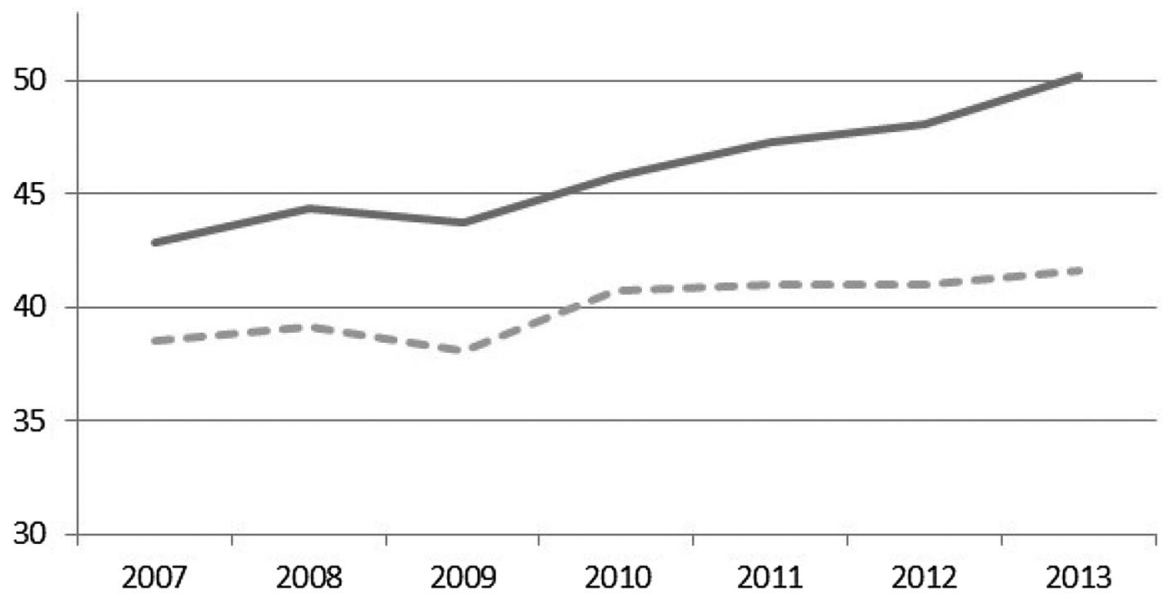

Note: NATs dotted line, FMNs solid line.

Fig. 6 NATs' and FMNs' labour cost per employee (2007-2013), post-counterfactual. Note: NATs dotted line, FMNs solid line

collected for the whole of Italy by Mariotti et al. (2008). This last finding might be due to the behaviour and characteristics of the FMNs, for example concerning their arbitrage in taxation and transfer pricing policy, their higher operating costs for facilities, their higher exposure to price fluctuations of raw materials, and their 


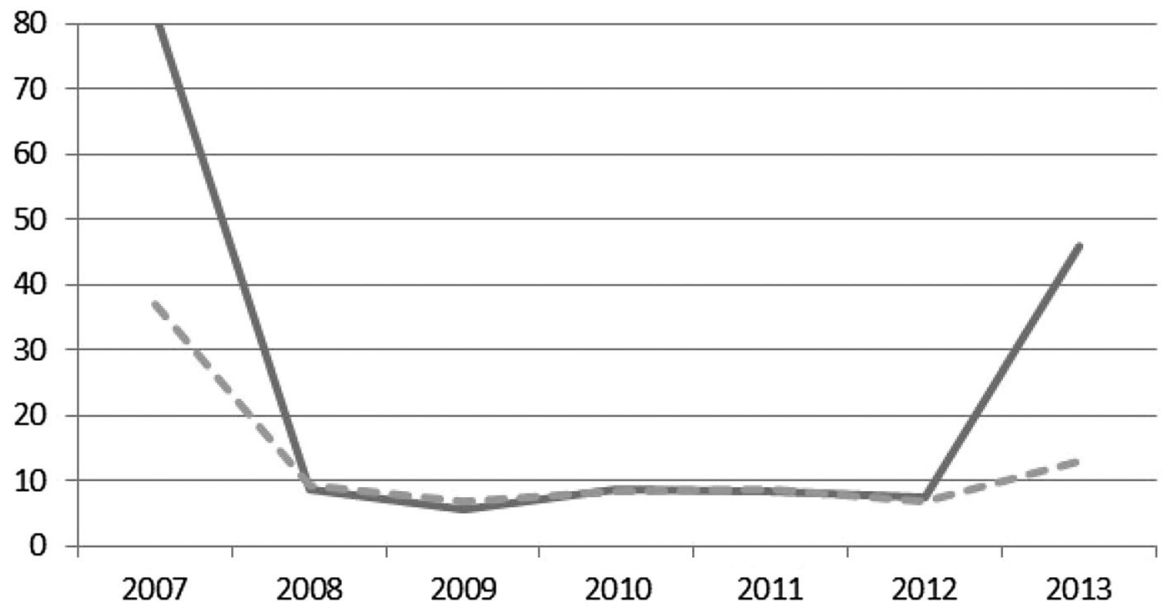

Note: NATs dotted line, FMNs solid line.

Fig. 7 NATs' and FMNs' ROI (2007-2013), post-counterfactual. Note: NATs dotted line, FMNs solid line

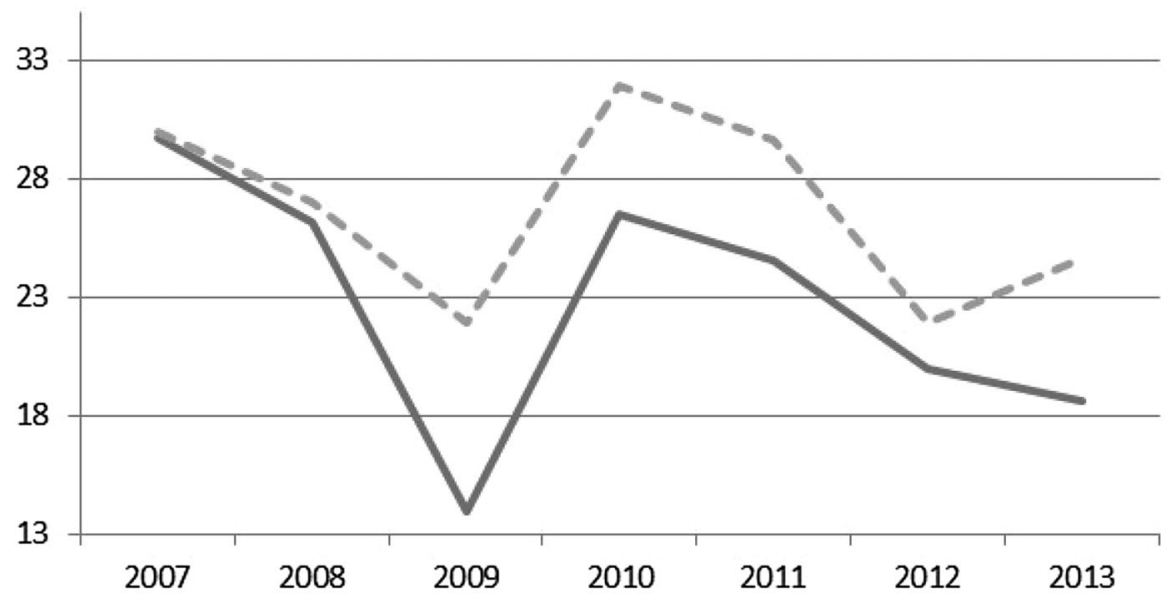

Note: NATs dotted line, FMNs solid line.

Fig. 8 NATs' and FMNs' operating profit per employee (2007-2013), post-counterfactual. Note: NATs dotted line, FMNs solid line

higher competition with large and productive companies (Basile et al. 2005; Mariotti and Mutinelli 2010). Furthermore, the analysis carried out with the aid of the p-score matching technique (Table 6) confirms that the FMNs pay higher wages to employ a larger highly-skilled labour force. This finding is consistent with previous 
Table 6 ATT estimation

\begin{tabular}{|c|c|c|c|c|c|c|}
\hline Variable & Year & NATs & FMNs & ATT & $\begin{array}{l}\text { Standard } \\
\text { Errors }\end{array}$ & $\begin{array}{l}\text { Signifi- } \\
\text { cance }\end{array}$ \\
\hline Share of high skilled workers & 2014 & 637 & 173 & 0.06 & 0.02 & $\begin{array}{l}\text { Statisti- } \\
\text { cally } \\
\text { signif- } \\
\text { icant }\end{array}$ \\
\hline Share of under 30 workers & 2014 & 637 & 173 & -0.04 & 0.01 & $\begin{array}{c}\text { Statisti- } \\
\text { cally } \\
\text { signif- } \\
\text { icant }\end{array}$ \\
\hline Share of women workers & 2014 & 637 & 173 & 0.03 & 0.02 & $\begin{array}{l}\text { Not } \\
\text { statis- } \\
\text { tically } \\
\text { signif- } \\
\text { icant }\end{array}$ \\
\hline Share of foreign workers & 2014 & 637 & 173 & -0.04 & 0.01 & $\begin{array}{c}\text { Statisti- } \\
\text { cally } \\
\text { signif- } \\
\text { icant }\end{array}$ \\
\hline Labour cost per employee & 2013 & 637 & 173 & 7.70 & 1.06 & $\begin{array}{l}\text { Statisti- } \\
\text { cally } \\
\text { signif- } \\
\text { icant }\end{array}$ \\
\hline Added value per employee & 2013 & 637 & 173 & 3.12 & 3.22 & $\begin{array}{l}\text { Not } \\
\text { statis- } \\
\text { tically } \\
\text { signif- } \\
\text { icant }\end{array}$ \\
\hline Operating profit per employee & 2013 & 637 & 173 & -4.89 & 3.54 & $\begin{array}{l}\text { Not } \\
\text { statis- } \\
\text { tically } \\
\text { signif- } \\
\text { icant }\end{array}$ \\
\hline
\end{tabular}

studies (Mariotti et al. 2008). Instead, the productivity level does not appear to be significantly higher than it is in the NATs control group.

In addition, labour skill is associated with age and nationality. FMNs employ a lower share of under-30 workers and a lower share of foreign workers compared to their NATs counterparts. This finding points to a substantial heterogeneity across types of firms in their workforce choices: FMNs tend to recruit more experienced/ mature (instead of young) and native workers (instead of foreigners), whereas single domestic firms seem to engage in employment behaviour which results in a higher share of young and foreign workers. Overall, and in line with our expectation, this finding supports the view that ownership has an influence on the internal workforce composition of companies. The results seem to suggest that the employment choices of FMNs privilege the use of inherited 'genomic, catalytic, organic and dynamic' (Kasabov and Sundaram 2016: 1529) competencies embedded in local industrial 
heritage by tapping into the stock of knowledge and skills of experienced local workers.

\section{Conclusions}

The present article compares FMNs and NATs and explores how firm ownership (foreign or national) affects the internal workforce composition of companies located in the Italian region of Veneto, a region globally renowned for its manufacturing production. The results of the econometric analysis preliminary to the counterfactual analysis pinpoint that FMNs are larger in terms of turnover than NATs, and are more open to high-tech sectors-in line with previous research (e.g. Castellani and Zanfei 2006). With regard to the employment choices relating to the internal workforce composition of companies, the counterfactual analysis_-in which FMNs are compared with a control group of NATs selected based on company similarities in terms of size, economic profile and sector-highlights that FMNs have a significantly higher probability of recruiting highly-skilled workers and paying higher wages. FMN workers tend to be more mature (older than 30 years) and national. In line with our expectation, this finding supports the view that ownership has an influence on the internal workforce composition of companies. The rationale behind the strategy of FMNs to hire workers who are more experienced and embedded in the local environment could be the need for these enterprises to reduce information asymmetry. The choice to employ a lower share of under-30 workers enables FMNs to tap into stock of knowledge and know-how embedded in experienced native workers. Overall, the decision of FMNs to employ national, experienced workers might strengthen the positive impact of the presence of FMNs in terms of boosting the use of idiosyncratic productive knowledge.

These results should be also read in the light of the Italian context, where: foreign workers are overwhelmingly low-educated and on temporary contracts; and, migration policies focus on restricting migration. These factors limit diversity (in the case under investigation, in terms of mix of foreign highly-qualified and less-qualified workers) and have important and long-lasting economic consequences. As recently highlighted by Rodríguez-Pose and von Berlepsch (2018) in their study looking at migrants' background diversity in the USA, encouraging migration and integration of migrants (low polarisation) allows diversity to be transformed into higher and durable economic activity over the short, medium and long term. Therefore, a tailored immigration policy is here advocated in Italy.

Given the specific temporal window under investigation, coinciding with the economic crisis, the present article introduces a human capital perspective to the studies showing that firms react heterogeneously to market risk and uncertainty according to their ownership status (e.g. Gagliardi and Iammarino 2018). The recent contribution by Gagliardi and Iammarino (2018) highlights how ownership-i.e. multinational enterprise versus single domestic enterprise-positively moderates the relationship between risk perception and firms' innovation behaviour. The different workforce composition in FMNs compared to NATs may play an important role in 
the accumulation of technological and organisational competence, providing fertile ground for enhancing innovation due to the combination of inherent capabilities and the skills of host-country nationals as well as the overall set of resources offered by FMNs' intra-firm networks.

This work does, however, have some limitations that offer valuable insights into possible directions for future research. Future research within the economic geography and international economics literature may focus on the implications of companies' choices in terms of their internal workforce composition across different types of firms (be they FMNs or NATs) on regional development and local resource systems (such as suppliers' networks and their labour composition, education system, public/associative institutions and financial system). The offshoring trends and the adoption of new technologies have led to a global reorganisation of production and service functions (Berger 2013; Pisano and Shih 2009, 2012). These transformations have affected workforce endowment and skills (for instance, in terms of demand for routine/non-routine jobs) in advanced economies (Barzotto and De Propris 2018; Gagliardi et al. 2015; Robert-Nicoud 2008). A deeper understanding of the employment behaviour adopted by FMNs and NATs is required in order to shed light on the extent to which domestic as well as foreign investments could sustain the regeneration of a host country's skilled human capital present in advanced economies. This is particularly crucial for advanced countries as they have seen the dissipation of their 'industrial commons' (that is, the set of external economies of localisationsuch as skilled workforces, supply networks, manufacturing cultures, social capital) due to extensive offshoring processes. These processes have led companies located in advanced economies to a progressively move away from their domestic productive ecosystem and control over key assets. The risk of complete erosion of the industrial commons is severely hindering the competitiveness of advanced economic areas in the long run (Pisano and Shih 2009, 2012). Employment choices of FMNs and NATs and the role of host-country nationals in FMNs may play a pivotal role in sustaining local resources, hence, the importance of investigating their impacts on the (re)generation of the industrial commons of advanced economies.

Acknowledgements The authors would like to thank the anonymous reviewers and the Editors for detailed and highly constructive comments during the review process. We gratefully acknowledge the support received from Bruno Anastasia, Maurizio Gambuzza and Maurizio Resera from Veneto Lavoro, who provided the data concerning employment in the Veneto region. An earlier version of this study was presented at the c.MET05 Workshop at the AIB in Milan (2015), the Global Value Chain Workshop in Birmingham (2015), the URSI seminar at the University of Groningen (2016), the ERSA congress in Vienna (2016), the Italian Association of Regional Studies (AISRe) Conference in Ancona (2016) and the Società Italiana di Economia e Politica Industriale - Annual Workshop in Palermo (2017). We thank all these audiences. All remaining errors are the authors'.

\section{Compliance with ethical standards}

Conflict of interest On behalf of all authors, the corresponding author states that there is no conflict of interest.

OpenAccess This article is distributed under the terms of the Creative Commons Attribution 4.0 International License (http://creativecommons.org/licenses/by/4.0/), which permits unrestricted use, distribution, 
and reproduction in any medium, provided you give appropriate credit to the original author(s) and the source, provide a link to the Creative Commons license, and indicate if changes were made.

\section{Appendix 1}

\section{List of highly skilled workers}

Managers

Professionals

Science and engineering, social and health professionals

Cultural professionals

Teaching specialists

Technicians and associate professionals

Science and engineering associate professionals

Production technicians

Health associate professionals

Business and administration associate professionals

Public and personal services associate professionals

\section{Appendix 2}

\begin{tabular}{llllr}
\hline Variable & Unmatched/matched & Mean for treated & Mean for control & Bias (\%) \\
\hline Size & Unmatched & 9.71 & 7.65 & 149.60 \\
& Matched & 9.62 & 9.63 & -0.90 \\
ROE & Unmatched & 8.27 & 7.03 & 4.80 \\
& Matched & 8.35 & 9.17 & -3.20 \\
Sector (medium/high-tech) & Unmatched & 0.46 & 0.24 & 48.30 \\
& Matched & 0.45 & 0.46 & -3.50 \\
Sector (medium/low-tech) & Unmatched & 0.26 & 0.39 & -29.80 \\
& Matched & 0.26 & 0.24 & 4.60 \\
Sector (low-tech) & Unmatched & 0.18 & 0.33 & -35.20 \\
& Matched & 0.19 & 0.20 & -4.10 \\
\hline Sample & Ps R2 & & MeanBias & MedBias \\
\hline Unmatched & 0.26 & 53.50 & & 35.20 \\
Matched & 0.01 & 3.20 & & 3.50 \\
\hline
\end{tabular}

We run the covariate imbalance testing, pstest, directly after the propensity score matching, command 'psmatch2'. If option 'both' is specified, pstest returns the following diagnostics of covariate balancing before and after matching: PS R2 is the 
pseudo R2 from probit estimation; MeanBias is the mean absolute standardised bias; and MedBias is the median absolute standardised bias

\section{References}

Aleksynska, M., \& Tritah, A. (2015). The heterogeneity of immigrants, host countries' income and productivity: A channel accounting approach. Economic Inquiry, 53(1), 150-172.

Alfaro, L., Chanda, A., Kalemli-Ozcan, S., \& Sayek, S. (2004). FDI and economic growth: The role of local financial markets. Journal of international economics, 64(1), 89-112.

Bandick, R. (2008). Is it profitable to work for multinationals in Sweden? In R. Bandick (Ed.), Multinationals, employment and wages: Microeconomic evidence from Swedish manufacturing. Örebro Örebro Studies in Economics. Örebro: University of Örebro.

Barba-Navaretti, G., Castellani, D., \& Disdier, A. C. (2009). How does investing in cheap labour countries affect performance at home? Firm-level evidence from France and Italy. Oxford Economic Papers, 62(2), 234-260.

Barba-Navaretti, G., Venables, A. J., \& Barry, F. (2006). Multinational firms in the world economy. Princeton: Princeton University Press.

Barbosa, N., \& Louri, H. (2005). Corporate performance: Does ownership matter? A comparison of foreign-and domestic-owned firms in Greece and Portugal. Review of Industrial Organization, 27(1), 73-102.

Barzotto, M., \& De Propris, L. (2018). Skill up: Smart work, occupational mix and regional productivity. Journal of Economic Geography. https://doi.org/10.1093/jeg/lby050.

Basile, R., Benfratello, L., \& Castellani, D. (2005). Attracting foreign direct investment in Europe. Are Italian regions doomed? Rivista di Politica Economica, 95(1-2), 319-354.

Becker, S. O., Ekholm, K., \& Muendler, M.-A. (2013). Offshoring and the onshore composition of tasks and skills. Journal of International Economics, 90(1), 91-106.

Becker, S. O., \& Ichino, A. (2002). Estimation of average treatment effects based on propensity scores. The Stata Journal, 2(4), 358-377.

Becker, S. O., \& Muendler, M.-A. (2008). The effect of FDI on job security. The BE Journal of Economic Analysis and Policy, 8(1), Article 8.

Bellak, C. (2004). How domestic and foreign firms differ and why does it matter? Journal of economic surveys, 18(4), 483-514.

Berger, S. (2013). Making in America: From innovation to market. Cambridge: MIT Press.

Blinder, A. S. (2009). How many US jobs might be offshorable? World Economics, 10(2), 41.

Blomstrom, M. \& Kokko, A. (2003). Human capital and inward FDI. Working Papers Series No. 167. The European Institute of Japanese Studies (Stockholm School of Economics, Sweden).

Bosetti, V., Cattaneo, C., \& Verdolini, E. (2015). Migration of skilled workers and innovation: A European perspective. Journal of International Economics, 96(2), 311-322.

Bratti, M., \& Conti, C. (2018). The effect of immigration on innovation in Italy. Regional Studies, 52(7), 934-947.

Brouwer, A., \& Mariotti, I. (2014). Firm heterogeneity in multinational and domestic firms in Italian logistics. European Transport, 56(8), 1-17.

Caliendo, M. (2008). Start-up subsidies in East Germany: Finally a policy that works? In I. D. P. Series (Ed.), Institute for the Study of Labor (IZA). Bonn: Institute for the Study of Labor (IZA).

Caprar, D. V. (2011). Foreign locals: A cautionary tale on the culture of MNC local employees. Journal of International Business Studies, 42(5), 608-628.

Castellani, D., \& Zanfei, A. (2006). Multinational firms, innovation and productivity. Cheltenham: Edward Elgard.

Caves, R. E., \& Caves, R. E. (1996). Multinational enterprise and economic analysis. Cambridge: Cambridge University Press.

Crinò, R. (2010). Employment effects of service offshoring: Evidence from matched firms. Economic Letters, 107, 253-256.

Crinò, R. \& Onida, F. (2007). Foreign ownership and economic performance in Italy: Not all is cherrypicking!, CESPRI WP 207, November. Milan, Italy: Bocconi University. 
De Backer, K. \& Sleuwaegen, L. (2003). Foreign ownership and productivity dynamics. Economics Letters, 79, 177-183.

De Benedictis, L. (2005). Three decades of Italian comparative advantages. World Economy, 28(11), 1679-1709.

De Mello, L. R. (1999). Foreign direct investment-led growth: Evidence from time series and panel data. Oxford Economic Papers, 51(1), 133-151.

Del Boca, D. \& Venturini, A. (2005). Italian migration. In K. F. Zimmermann (Ed.), European migration: What do we know? (pp. 301-336). Oxford: Oxford University Press.

Dell'Aringa, C., Lucifora, C., \& Pagani, L. (2015). Earnings differentials between immigrants and natives: The role of occupational attainment. IZA Journal of Migration, 4, 1-18.

Doms, M. E., \& Jensen, J. B. (1998). Comparing wages, skills, and productivity between domestically and foreign-owned manufacturing establishments in the Unites States. In R. Baldwin, R. Lipsey, \& J. Richardson (Eds.), Geography and ownership as bases for economic accounting, Studies in Income and Wealth (Vol. 59, pp. 235-255). Chicago: The University of Chicago Press.

Douma, S., George, R., \& Kabir, R. (2006). Foreign and domestic ownership, business groups, and firm performance: Evidence from a large emerging market. Strategic Management Journal, 27(7), 637-657.

Driffield, N., \& Taylor, K. (2000). FDI and the labour market: A review of the evidence and policy implications. Oxford Review of Economic Policy, 16(3), 90-103.

Etzo, I., Massidda, C., Mattana, P., \& Piras, R. (2017). The impact of immigration on output and its components: A sectoral analysis for Italy at regional level. Economia Politica, 34(3), 533-564.

EUROSTAT. (2015). Manufacturing statistics-NACE Rev. 2; http://ec.europa.eu/eurostat/statistics -explained/index.php/Manufacturing_statistics_-_NACE_Rev._2\#Further_Eurostat_information.

Fassio, C., Montobbio, F., \& Venturini, A. (2018). Skilled migration and innovation in European industries. Research Policy. https://doi.org/10.1016/j.respol.2018.11.002.

Feyrer, J. D. (2008). Aggregate evidence on the link between demographics and productivity. In A. Prskawetz, D. Bloom, \& W. Lutz (Eds.), Population aging, human capital accumulation and productivity growth, population and development review. A supplement to Vol. 34, Population And Development Review (pp. 78-99). New York: Population Council.

Forte, R., \& Moura, R. (2013). The effects of foreign direct investment on the host country's economic growth: Theory and empirical evidence. The Singapore Economic Review, 58(03), 1350017.

Frosch, K. H. (2011). Workforce age and innovation: A literature survey. International Journal of Management Reviews, 13(4), 414-430.

Gagliardi, L. (2015). Does skilled migration foster innovative performance? Evidence from British local areas. Papers in Regional Science, 94(4), 773-794.

Gagliardi, L., \& Iammarino, S. (2018). Innovation in risky markets: Ownership and location advantages in the UK regions. Journal of Economic Geography, 18(5), 1177-1201.

Gagliardi, L., Iammarino, S., \& Rodríguez-Pose, A. (2015). Offshoring and the geography of jobs in Great Britain (185). London: Spatial Economics Research Centre.

Girma, S., \& Görg, H. (2007). Evaluating the foreign ownership wage premium using a difference-indifferences matching approach. Journal of International Economics, 72(1), 97-112.

Giuri, P., Mariani, M., Brusoni, S., Crespi, G., Francoz, D., Gambardella, A., et al. (2007). Inventors and invention processes in Europe: Results from the PatVal-EU survey. Research Policy, 36(8), 1107-1127.

Globerman, S., Ries, J. C., \& Vertinsky, I. (1994). The economic performance of foreign affiliates in Canada. Canadian Journal of Economics, 27, 143-156.

Griffith, R., \& Simpson, H. (2004). Characteristics of foreign-owned firms in British manufacturing. Seeking a premier economy: The economic effects of British economic reforms, 1980-2000 (pp. 147-180). Chicago: University of Chicago Press.

Head, K., \& Ries, J. (2002). Offshore production and skill upgrading by Japanese manufacturing firms. Journal of International Economics, 58(1), 81-105.

Heckman, J., Ichimura, H., \& Todd, P. (1997). Matching as an econometric evaluation estimator: Evidence from evaluating a job training program. Review of Economic Studies, 64, 605-654.

Henseke, G., \& Tivig, T. (2009). Demographic change and industry-specific innovation patterns in Germany. Labour Markets and Demographic Change (pp. 122-136). Berlin: Springer.

Huber, P., \& Tondl, G. (2012). Migration and regional convergence in the European Union. Empirica, 39(4), 439-460. 
Hunt, J., \& Gauthier-Loiselle, M. (2010). How much does immigration boost innovation? American Economic Journal: Macroeconomics, 2(2), 31-56.

Hyun, H.-J., Oh, C. H., \& Paik, Y. (2015). Impact of nationality composition in foreign subsidiary on its performance: A case of Korean companies. The International Journal of Human Resource Management, 26(6), 806-830.

Ilmakunnas, P., Maliranta, M., \& Vainiomäki, J. (2004). The roles of employer and employee characteristics for plant productivity. Journal of productivity analysis, 21(3), 249-276.

ISTAT. (2015). L'integrazione degli stranieri e dei naturalizzati nel mercato del lavoro. Statistiche report. Available online at: https://www.istat.it/it/files//2015/12/Lavoro_stranieri.pdf. Accessed 25 Feb 2019.

ISTAT. (2016). Struttura e competitività delle imprese multinazionali-Anno 2014. Statistiche report. Available online at: https://www.istat.it/it/files//2016/11/Struttura-e-competitivit\%C3\%A0-delle -multinazionali-2014_new.pdf. Accessed 25 Feb 2019.

ISTAT. (2017). Rapporto annuale 2017. La situazione del Paese: ISTAT.

Jensen, P. H. (2014). Understanding the impact of migration on innovation. Australian Economic Review, 47(2), 240-250.

Jensen, J. B., \& Kletzer, L. G. (2010). Measuring tradable services and the task content of offshorable services jobs, Labor in the New Economy (pp. 309-335). Chicago: University of Chicago Press.

Jones, B. F. (2005). Age and great invention: NBER Working paper 11359. Cambridge, MA: National Bureau of Economic Research.

Kangasniemi, M., Mas, M., Robinson, C., \& Serrano, L. (2012). The economic impact of migration: Productivity analysis for Spain and the UK. Journal of Productivity Analysis, 38(3), 333-343.

Kasabov, E., \& Sundaram, U. (2016). Conceptualizing clusters as dynamic and path-dependent pools of skills. Regional Studies, 50(9), 1520-1536.

Kerr, W. R., \& Lincoln, W. F. (2010). The supply side of innovation: H-1B visa reforms and US ethnic invention. Journal of Labor Economics, 28(3), 473-508.

Leuven, E. \& Sianesi, B. (2003). PSMATCH2: Stata module to perform full Mahalanobis and propensity score matching, common support graphing, and covariate imbalance testing. Statistical Software Components S, 432001. Boston College Department of Economics.

Lipsey, R. E., \& Sjöholm, F. (2005). The impact of inward FDI on host countries: Why such different answers?. Washington, DC: Institute for International Economics.

Loungani, P., \& Razin, A. (2001). How beneficial is foreign direct investment for developing countries? Finance and Development, 38(2), 6-9.

Lovison, M. (2005-2006). Tessile, abbigliamento. Trama e ordito di persone e capitali. Padova: Università di Padova.

Malmberg, B., Lindh, T., \& Halvarsson, M. (2008). Productivity consequences of workforce aging: Stagnation or Horndal effect? Population and Development Review, 34, 238-256.

Mariani, M., \& Romanelli, M. (2007). "Stacking" and "picking" inventions: The patenting behavior of European inventors. Research Policy, 36(8), 1128-1142.

Mariotti, S. \& Mutinelli, M. (2010). Italia multinazionale 2010. Le partecipazioni italiane all'estero ed estere in Italia. Soveria Mannelli: Rubbettino Editore.

Mariotti, S., Mutinelli, M., \& Piscitello, L. (2008). The internationalization of production by Italian industrial districts' firms: Structural and behavioural determinants. Regional Studies, 42(5), 719-735.

Mariotti, S., Mutinelli, M. \& Sansoucy, L. (2014). Italia multinazionale 2014. Le partecipazioni italiane all'estero ed estere in Italia. Soveria Mannelli: Rubbettino Editore.

Morrison, C., \& Sacchetto, D. (2016). Catene del lavoro e delle migrazioni tra Veneto e Romania. Quaderni di ricerca sull'artigianato, 4(3), 401-422.

Niebuhr, A. (2010). Migration and innovation: Does cultural diversity matter for regional R\&D activity? Papers in Regional Science, 89(3), 563-585.

Nieto, S., Matano, A., \& Ramos, R. (2015). Educational mismatches in the EU: Immigrants vs natives. International Journal of Manpower, 36(4), 540-561.

O'Donnell, S., \& Blumentritt, T. (1999). The contribution of foreign subsidiaries to host country national competitiveness. Journal of International Management, 5(3), 187-206.

OECD (Organisation for Economic Co-Operation and Development). (2008a). Policy brief. The social impact of foreign direct investment. In OECD Observer, July. Paris: OECD. 
OECD (Organisation for Economic Co-Operation and Development). (2008b). Do multinationals promote better pay and working conditions? In OECD Employment Outlook 2008. Paris: OECD Publishing. https://doi.org/10.1787/empl_outlook-2008-7-en.

Østergaard, C. R., Timmermans, B., \& Kristinsson, K. (2011). Does a different view create something new? The effect of employee diversity on innovation. Research Policy, 40(3), 500-509.

Ozgen, C., Nijkamp, P., \& Poot, J. (2017). The elusive effects of workplace diversity on innovation. Papers in Regional Science, 96, S29-S49.

Ozturk, I. (2007). Foreign direct investment-growth nexus: A review of the recent literature. International Journal of Applied Econometrics and Quantitative Studies, 4(2), 79-98.

Paserman, M. D. (2013). Do high-skill immigrants raise productivity? Evidence from Israeli manufacturing firms, 1990-1999. IZA Journal of Migration, 2, 6.

Peri, G. (2012). The effect of immigration on productivity: Evidence from US states. Review of Economics and Statistics, 94(1), 348-358.

Perrotta, D. C. \& Sacchetto, D. (2009). Flussi di investimento e destini della forza lavoro: il caso del tessile e abbigliamento. Rapporto COSES n. 139, Venezia.

Pisano, G. P., \& Shih, W. C. (2009). Restoring American competitiveness. Harvard Business Review, $87(7 / 8), 114-125$.

Pisano, G. P., \& Shih, W. C. (2012). Does America really need manufacturing? Harvard Business Review, 90(3), 94-102.

Porter, M. E. (1985). Competitive advantage. New York: Free Press.

Prometeia. (2014). L'impatto delle acquisizioni dall'estero sulla performance delle imprese italiane. In ITA (Italian Trade Agency) Edition.

Robert-Nicoud, F. (2008). Offshoring of routine tasks and (de) industrialisation: Threat or opportunityAnd for whom? Journal of Urban Economics, 63(2), 517-535.

Rodríguez-Pose, A., \& von Berlepsch, V. (2018). Does population diversity matter for economic development in the very long term? Historic migration, diversity and county wealth in the US. European Journal of Population. https://doi.org/10.1007/s10680-018-9507-z.

Rubin, D. B. (1974). Multivariate matching methods that are equal percent bias reducing, II: Maximums on bias reduction for fixed sample sizes. ETS Research Bulletin Series, 1974, 1-26.

Rueda-Cantuche, J. M., Sousa, N., Andreoni, V., \& Arto, I. (2012). The Single Market as an engine for employment growth through the external trade. Seville: Joint Research Centre, IPTS.

Saxenian, A. (2006). The new argonauts. Cambridge, MA: Harvard University Press.

Simonton, D. K. (1988). Age and outstanding achievement: What do we know after a century of research? Psychological Bulletin, 104(2), 251.

Simonton, D. K. (2007). Creativity. In J. Birren (Ed.), The Encyclopedia of Gerontology (pp. 341-351). San Diego, CA: Academic Press.

Sylwester, K. (2005). Foreign direct investment, growth and income inequality in less developed countries. International Review of Applied Economics, 19(3), 289-300.

UNCTAD. (1994). World Investment Report 1994. New York and Geneva: UNCTAD.

Zaheer, S. (1995). Overcoming the liability of foreignness. Academy of Management Journal, 38(2), 341-363.

Zheng, Y., \& Ejermo, O. (2015). How do the foreign-born perform in inventive activity? Evidence from Sweden. Journal of Population Economics, 28(3), 659-695.

Publisher's Note Springer Nature remains neutral with regard to jurisdictional claims in published maps and institutional affiliations. 


\section{Affiliations}

\section{Mariachiara Barzotto ${ }^{1}(1) \cdot$ Giancarlo Corò $^{2} \cdot$ Ilaria Mariotti ${ }^{3} \cdot$ Marco Mutinelli $^{4}$}

Giancarlo Corò

corog@unive.it

Ilaria Mariotti

ilaria.mariotti@polimi.it

Marco Mutinelli

marco.mutinelli@unibs.it

1 Newcastle University Business School, University of Newcastle, 5 Barrack Rd, Newcastle upon Tyne NE1 4SE, UK

2 Department of Economics, Ca' Foscari University, Cannaregio 873, Fondamenta San Giobbe, 30121 Venice, Italy

3 Department of Architecture and Urban Studies, Polytechnic University of Milan, Piazza L. Da Vinci, 32, 20133 Milan, Italy

4 Department of Mechanical and Industrial Engineering, University of Brescia, Piazza del Mercato, 15, 25121 Brescia, Italy 